\author{
M. I. Zvieriakov, Corr. Member of the NAS of Ukraine, \\ Dr. Sc. (Econ.), Prof., \\ orcid.org/0000-0003-0039-5068, \\ D. V.Zavadska, Cand. Sc. (Econ.), Assoc. Prof., \\ orcid.org/0000-0003-2950-554X
}

Odesa National Economic University, Odesa, Ukraine, e-mail: rector@oneu.edu.ua; zavadska.diana@ukr.net

\title{
MODEL OF INTENSIVE INNOVATIVE DEVELOPMENT: WORLD EXPERIENCE OF IMPLEMENTATION AND TRENDS OF FORMATION IN UKRAINE
}

Purpose. To develop recommendations for implementing innovative models of intensive development in Ukraine.

Methodology. The information base of the research is data reviews with the innovative development of scientific achievements and results of Ukrainian and foreign scientists, published in monographs and publications in periodicals. The official statistical base is the data of international organizations and leading scientific institutions of Ukraine. During the research, methods of tabular and graphical representation of the research results, logical generalization, comparative analysis and system approach, taking into account the dynamic functional dependence between the state of the whole, development and the balance of its constituent elements, were used.

Findings. The work emphasizes that the problem of economic growth and innovation development has become especially significant. It has been proved that the model of intensive innovative development is intended to provide structural changes in the economic state of the country and improve its technological level. The critical analysis of the scientific achievements of leading scientists and the assessment of the current state of the national innovation system of Ukraine allowed us to reach a conclusion on the lack of mechanisms for "launching" an innovation model which is adequate to the current state of the economy and global challenges of the world. In order to achieve a synergistic effect and sustainable growth of the national economy of Ukraine, practical measures have been proposed to influence the state regulation of innovation activity.

Originality. The work shows the special role of the National Council of Science and Technology as the integrator, designed for implementing specific management functions aimed at improving coordination of innovation policy of Ukraine.

Practical value. The scientific research clearly and consistently proves the urgent need for transition and implementation of the model of the fourth spiral of innovative development of the Ukrainian economy. The results will continue to be used to develop recommendations to identify areas of financial security in order to enhance the country's innovation processes.

Keywords: economic theory, concept of growth, innovative development, model, approach, state, regulatory tools, coordination

Introduction. Innovative way of economic development in real time is the benchmark for most developed economies in the world. Ukraine faces the challenge of qualitative renewal of socio-economic life. These tasks are dictated by external "big challenges" of a global nature, as well as internal processes [1]. In order to withstand the challenges and minimize risks, Ukraine needs to get out of the raw material model of growth, which has certain threats to the stability of socio-economic development. For Ukraine, this problem is particularly acute as the level of innovation development is far behind both the industrialized countries and the countries that have recently recognized the need to move to an economy of innovation type.

The problem of low efficiency of resource use, the high production cost at micro and macro levels, lack of restructuring, stagflation, progressive relative overproduction crisis and a significant reduction in aggregate demand in the traditional structure of the national economy update the need for finding ways of innovative development. One of the main problems of the crisis,

(C) Zvieriakov M. I., Zavadska D. V., 2018 which is associated with a feature of the technological state of the economy of Ukraine, is a direct state intervention in the economy through fiscal and monetary macroeconomic policies. Therefore, the establishing of effective mechanisms for innovative technological changes that lead to economic restructuring, acquire special significance.

Analysis of the recent research and publications. The theoretical and practical aspects of innovative development of the economy take the leading place in the works of both foreign and domestic scientists. Theoretical foundations of innovative development and recommendations on the mechanism of its financial support were developed by M.Kondratiev, G.Mensch, S. Hlaziev, Y. Yakovets, M. Denisenko. The leading domestic researchers in solving the issues of developing an innovative economy are: O. Amosha, V. Heiets, M. Dolishnii, M. Zvieriakov, S. Onyshko, T. Paientko, A. Kuznietsova, L. Fedulova, I. Irtyscheva and many others.

In their works, the researchers also analyzed some aspects of innovation development in the EU countries and the possibilities of using foreign experience to achieve the strategic goal of Ukrainian society development. 
Unsolved aspects of the problem. The European choice of Ukraine on the way to integration into a hightech competitive environment led to the need to form and implement an innovative development model that was supposed to ensure high and stable rates of economic growth, solve certain social and environmental problems, provide competitiveness of the national economy, increase the export potential of the country, ensure its safety and a prominent position in the European Union.

However, in practice, after the proclamation of the course on integration into the world economic space, innovation development has not become one of the main characteristics of the national economic growth of Ukraine. There were positive tendencies for several years, but they were mostly temporary and weak shifts in the economy, which characterizes innovation processes in Ukraine as unstable and lacking clear long-term incentives for innovation.

While acknowledging the achievements of domestic and foreign scientists in the field of the theory and organization of innovation development, it is worth noting that the specific ways of implementation and adaptation of world experience of innovative development of the Ukrainian economy have not found their final application so far as well as, accordingly, management of innovative development, which caused the relevance of this topic.

Objectives of the article. Due to the objective necessity of reproducing the full cycle of innovation activity as the most important factor of sustainable socio-economic development of Ukraine, the problem of providing innovative capacity as a set of institutions, policies and factors has acquired special significance.

The need to fulfill the strategic objectives of innovative development of national economy requires research processes of leading national models of innovative development that meet modern conditions of globalization and objectives for innovation development of economy of Ukraine and the theoretical bases of practical measures for modern tools of state regulation of innovation influencing the economic growth, which determined the purpose of our study.

The study aims to develop recommendations for implementation of the model of intensive innovative development in Ukraine.

Description of methodology (structure and sequence) of the study. To achieve this goal the following methods were used: systemic approach, theoretical synthesis, comparison, tabular and graphical presentation of research results. The information base of the study consists of data from reviews on innovative development of countries and scientific developments of Ukrainian and foreign scientists on the problem under investigation. The official statistical base is the data of international organizations and leading scientific institutions of Ukraine.

The structure of the article is as follows: to analyze the theoretical research on innovative development; to identify features of the implementation of innovation policy instruments of the world's countries and Ukraine in accordance with the concepts and periods of innova- tion and economic growth; to investigate the current state of Ukraine's transition process to the model of intensive innovative development of the economy; to propose measures to create opportunities for economic growth through innovation in Ukraine.

Presentation of the main research and explanation of the scientific results. The analysis of economic literature allowed concluding that in the conditions of an unprecedented aggravation of international competition for markets and limited natural resources that are being rapidly depleted, there are chances to preserve their economic sovereignty in the twenty-first century only for those states that, at an accelerated pace, accumulate advanced industrial capital, based on the use of recent achievements in science and technology.

With many different theories justifying the futility of resource orientation of economic growth adopted in most countries with transition economy, in the process of technical and technological modernization of the real economy, the development of science, technology and innovation sphere they primarily have given priority to industry and financing innovation.

Evolution of theoretical and empirical research on innovation development. The search for innovative development models and the identification of favorable conditions for innovation have become an important part of the process of creating theoretical foundations of innovation development. The analysis of the development of theoretical studies made it possible to conclude that current scientific debates about the logic of innovation development are built around the dichotomy of two approaches - the market primacy (the concept of demand or subversive innovations - demand-pull(market-pull): the change of consumer priorities, market conditions, new market models, and others) and technological determinism (breakthrough technologies - technologypush: globalization of research and development, knowledge economy formation, innovative solutions, and others).

Among the authors of scientific papers, proving the benefits of the first approach, it is advisable to highlight the thesis of C. Christensen and M. Rejnor, which has been introduced in "The Innovator's Solution: Creating and Sustaining Successful Growth" (2014). In their opinion, market theory of innovation development focuses on the problems of meeting latent solvent demand by combining already existing technologies ("subversive innovations") and changing the price-quality ratio. However, the authors note that there is no direct link between commercially feasible innovations, the subversive potential of innovation, technology and scienceintensity of the company-creator.

In accordance with technological determinism, scientific and technological progress and breakthrough technologies are the determining factor in development. This approach is the most clearly represented by theories of technological cycles, technologies of widespread use, innovation pauses and systemic decentralized nonlinear character of innovation development.

The researchers of the technological cycles approach have proved that a new stage in economic development, 
expressed in higher values of GDP growth, labor productivity and other macroeconomic indicators, is due to the evolution of science and the development of technology groups ("cumulative elements") that have a systemic transformational impact on various sectors of the economy (M. Tugan-Baranovsky, M. Kondratiev, Y.Schumpeter, J. Bernal). These conclusions are confirmed by Simon Kuznets in his Nobel prize lecture "Modern Economic Growth: Findings and Reflections" (1971). He emphasized that just epoch-making innovations and the potential of the basic innovations' waves that are implementing them, are based on the transition of not only the economy, but the society as a whole from one degree to another.

Gerhard Mensch deepens these issues in his scientific paper "Technological stalemate: innovation overcomes depression" (1975) and adds "innovative waves", the mechanism of interconnection between inventions, innovations and the level of economic activity. The scholar concluded that under conditions of depression, when the economy is structurally ready for the transition to new basic innovations, overcoming the "technological pothole" is possible only through innovations.

Developing the theory of technological determinism, T.Bresnahan and M. Trajtenberg discussed the "technology of wide application" as its central concept in the article "General Purpose Technologies: "Engines of Growth?" (1995). According to the authors' opinion, this technology allows the possibility of its application in the scale of the economy (technological complementarity) and has a significant potential for development and is constantly improved, which promotes the emergence of innovations in creating goods, services and processes, preventing the reduction of the impact of factors of production and, thus, supporting economic growth.

We note that the modern development of the theory under study is carried out in the conditions of a longstanding global crisis. In this regard, it is worth mentioning the hypothesis on innovation pause introduced by Victor Polterovych ("The hypothesis on innovation pause and the modernization strategy", 2009), based on the idea of G. Mensch about uneven innovative processes and alternating phases of boom and bust. The scientist suggested that global cyclical crises arise as a result of an innovation pause, when the existing technologies of widespread use have already exhausted their ability to support economic growth, and the new ones are not ready to hinder the reduction of the returns of production factors.

At the same time, the high level of uncertainty inherent to general-purpose technologies complicates the long-term forecast of economic growth. Delayed development of general-purpose technologies, in turn, leads to stagnation. In other words, the old basic innovations (information technology, computers and the Internet), which form the foundation of the $\mathrm{V}$ technology, do not generate a sufficient number of secondary innovations that can provide an increase in the efficiency of the production factors, and new basic innovations have not emerged yet.

The conclusion about the exhaustion of the technological capabilities of the $\mathrm{V}$ technological process should be considered fully justified. If we take into account the average length of the technological process in 4050 years, then the time limit has already been practically exhausted in the $\mathrm{V}$ technological process, which was formed in the early 1970s. This is evidenced by the deceleration of economic growth, even in the developed countries.

Hlaziev S. notes that the world economy has entered a period of long-term depression, during which there will be waves of recessions and minor upsurge [2]. It should be marked that with the emergence of innovation pauses in traditional economic sectors, serving as system customers and consumers of innovation and technology industries products, long-term stagnation processes, caused by weakening of growth rates of productivity, will occur.

We share the authors' opinion [3-5] that stagnation, which is associated with structural changes - the change in the industrial stage of innovation, can be overcome by accelerating economic growth at the expense of new sources (factors that are traditionally taken into account in aggregate factor productivity).

We consider it necessary to add that modern theories of innovation development emerged in response to the growing polarization of the global space. In an innovative economy, the key role is taken by networks or a system designed for the effective dissemination of knowledge and information, and science is embedded in the system of production and diffusion of knowledge. According to ideas of Richard Florida, Dani Rodrik ("Towards the Learning Region", 1995 and "Premature deindustrialization", 2016 corresponding to mentioned above) and other famous researchers, the concept of systemic decentralized non-linear character of innovation development: innovation environment, economic cluster and territorial innovation systems are of interest for consideration.

Roberto Camagni and supporters of the concept of innovation environment such as J. Podolny, K. Page and E. Schamp concluded in their scientific research ("Innovation networks: spatial perspectives", 1991; "Network form organization", 1998; "Globale Wertschöpfungsketten", 2008) that the reduction of the high-risk innovation process is facilitated by internal regional relations, cultural environment and social capital. Scientists prove that spatial proximity between actors and the organization of cooperative relations with external structures allow enterprises to gain access to new knowledge, markets and technologies.

Developing F.Peru's idea of the spatial economic growth, an American scientist Michael E. Porter in his article "Cluster and the New Economic of Competition", 1988 identified a fundamentally new structural element in the aggregate business competition - a cluster, as the best means of organizing the economy, which initiates processes of progressive inter-sectoral structures, develops advanced (network) forms of interaction between various economic entities, that together with competitiveness factors (human and natural resources, financial capital, infrastructure, conditions of regional demand; availability of related and supporting indus- 
tries; organizational structure, strategy, intensity, local competition) causes the emergence of positive effects of economic growth in the region.

The concept of territorial innovation systems presented at the national and regional levels by Clayton M. Christensen and Michael E. Rejnor ("The Innovator's Solution: Creating and Sustaining Successful Growth", 2013) is based on a system of interconnections among science, education, production, authorities and consumers. Moreover, scientists emphasize the specifics of the institutional structure of the country, which involves the technological interaction of firms in the process of $\mathrm{R} \& \mathrm{D}$ and promotes the dissemination of innovative technologies.

Taking into account the results obtained by scientists from different countries at different periods of the world and national economies, we will conclude that the process of technological change is carried out in an evolutionary way, involves the materialization of the latest advances in scientific and technological progress, gradual and qualitative changes in the spheres of production and consumption, and is a vector for the development of a new technological structure. The concept of intensive innovative development of the country's economy, as an alternative to its extensive economic growth, has now become a dominant doctrine which is the basis of the state policy of development.

The next step is to study the international experience of national innovation systems, the evolution of concepts of growth and approaches to using priority of state participation in funding $R \& D$.

Features of implementation of innovation policy instruments of the world countries and Ukraine in accordance with the concepts and periods of innovation and economic growth. According to the strategy of innovation development of a number of industrialized and developed economies, the authors pointed out five stages of innovation and economic development and identified the specifics of implementing innovative policy instruments (Table). We should note that the leading national model of innovation development is a reflection of the concept of growth theory, whose change is associated with the challenges of the gradual development of a new technological structure. The analysis of the literature on the evolution of the growth theory's concepts defined that classical, Keynesian, neoclassical, including monetarist theory, emerged in the late nineteenth century. However, in this study, the classic concept of growth is not presented for several reasons.

First of all, according to the classical concept, the basis of economic growth is the increase in real investment in the economy, the source of investment is the accumulation of economic entities, producers and consumers, and the role of the state is to create a competitive environment, the development of free international trade.

Secondly, the main instruments for providing growth and stability are the central bank discount rates, currency, monetary and fiscal policies, the implementation of which is possible with relative stability in the labor market, capital, currency, goods and services markets, and others.
From the foregoing, we note that the application of the concept is impossible in terms of disrupting the savings accumulation system and creating investments, destructing the credit and banking system, a significant decline in production. It was exactly the situation that accompanied America in the late 1920s - early 1930s of the $20^{\text {th }}$ century during the Great Depression and the times of the countries' restoration after the Second World War. Therefore, in order to overcome the situation, new growth concepts were needed.

The specificity of the traditional approach (19501981) reflects the state priorities inherent in the Keynesian model of economic growth. The application of the concept to the countries of the Euro-Atlantic region with a developed market economy (Canada, Denmark, Finland, France, Germany, Great Britain, Italy, the Netherlands, Sweden, Switzerland, the USA) provided the maximum possible state intervention in the economic processes: budget support and implementation of large investment labor-intensive projects (construction of roads, ports, communication hubs); direct control over building-up budget deficits through cash issues and using newly issued money; carrying out an active import-substituting policy; protectionism in relation to goods produced in the country (preferential taxation, subsidies, administrative methods); support for stability of the national currency.

The main tool for supporting large-scale projects, industries and technologies is the perpetual direct financing of fundamental research, formation of scientific infrastructure and support for a large business and R\&D cooperation by state order.

The dominant model of innovation at the macro level, according to this approach, is the model of a complete innovation cycle. In Western European countries that use this model, all elements of the national innovation system, including fundamental and applied science, R\&D, development of prototypes and launching them into mass production, are represented.

At the same time, extensive methods of economic development, used by the countries in the late 1960s early 1970 s, missed the possibility of the potential application of new technologies, which caused interest in the development of the neoclassical concept of growth theories.

In the 1980 s - 1990s monetary concept of growth was widely used. In relation to our study, this concept was most fully exploited by the countries of the Euro-Atlantic region during the development of an industrial approach. The period of 1982-1999 (industrial approach) was characterized by the growth of economic interdependence of countries, increase in inflationary processes and other negative phenomena in the sphere of money circulation. The main role of government is to conduct a stabilizing monetary policy (strict monetary limitation, budget deficit, using direct budgetary investment instruments and subsidized production, reduction of state expenditures), maximum liberalization of foreign economic activity, active participation in the international division of labor.

The state pays considerable attention to commercialization, financing innovative projects, in particular 
Features of the state's participation in the innovation and economic growth of the world countries [5-11]

\begin{tabular}{|c|c|}
\hline \multicolumn{2}{|c|}{$\begin{array}{c}\text { FIRST STAGE. } \\
\text { Traditional Target Approach } \\
\quad(1950-1981)\end{array}$} \\
\hline $\begin{array}{l}\text { Priority directions of state participation in } R \& D \text { : military- } \\
\text { industrial complex, nuclear power, space, oil }\end{array}$ & \multirow{2}{*}{$\begin{array}{l}\text { SPECIFICITY OF THE PERIOD: } \\
\text { state priorities } \\
\text { Production in the interests of the state and for the benefit of society } \\
\text { as a nation. } \\
\text { Prioritization "from top to bottom"; big research institutes. } \\
\text { Large-scale projects, industries and technologies }\end{array}$} \\
\hline $\begin{array}{l}\text { Support instruments for } R \& D \text { and innovation: } \\
\text { large-scale, direct financing of fundamental research; } \\
\text { development of scientific infrastructure; government orders }\end{array}$ & \\
\hline $\begin{array}{l}\text { Leading national model of innovation development: } \\
\text { Euro-Atlantic (Canada, Denmark, Finland, France, } \\
\text { Germany, Great Britain, Italy, the Netherlands, } \\
\text { Sweden, Switzerland, the USA) }\end{array}$ & $\begin{array}{l}\text { CONCEPT OF GROWTH THEORY: } \\
\text { Keynesian concept of growth } \\
\text { Maximum interference of the state in the economic processes. } \\
\text { Creating solvent demand for end-use consumer goods }\end{array}$ \\
\hline \multicolumn{2}{|c|}{$\begin{array}{l}\text { SECOND STAGE. } \\
\text { Industrial approach } \\
\quad(1982-1999)\end{array}$} \\
\hline $\begin{array}{l}\text { Priority directions of state participation in } R \& D \text { : } \\
\text { Mass automobile industry, aviation, electronics, } \\
\text { communications, nanotechnology and biotechnology, } \\
\text { new materials }\end{array}$ & \multirow{2}{*}{$\begin{array}{l}\text { SPECIFICITY OF THE PERIOD: } \\
\text { Social priorities } \\
\text { Focus on economies of scale and benefits for society (people), not } \\
\text { just for the state. } \\
\text { Planning, forecasting and assessing the technology; } \\
\text { national technological programs. } \\
\text { Civilian industries and technologies }\end{array}$} \\
\hline $\begin{array}{l}\text { Support instruments for } R \& D \text { and innovation: } \\
\text { large-scale project financing; operational administration; } \\
\text { commercialization of scientific knowledge }\end{array}$ & \\
\hline $\begin{array}{l}\text { Leading national model of innovation development: } \\
\text { Euro-Atlantic (Canada, Denmark, Finland, France, } \\
\text { Germany, Great Britain, Italy, the Netherlands, } \\
\text { Sweden, Switzerland, the USA) }\end{array}$ & $\begin{array}{l}\text { CONCEPT OF GROWTH THEORY: } \\
\text { Monetarist concept of growth } \\
\text { Maximum liberalization of foreign economic activity, activation of } \\
\text { participation in the international division of labor. } \\
\text { Stabilizing Monetary Policy }\end{array}$ \\
\hline \multicolumn{2}{|c|}{$\begin{array}{l}\text { THIRD STAGE. } \\
\text { System approach } \\
(2000-2008)\end{array}$} \\
\hline $\begin{array}{l}\text { Priority directions of state participation in } R \& D \text { : } \\
\text { mobile communication, the internet, social networks, } \\
\text { venture market }\end{array}$ & \multirow{2}{*}{$\begin{array}{l}\text { SPECIFICITY OF THE PERIOD: } \\
\text { Market priorities } \\
\text { Market interests, defined as "bottom-up", nonlinearity of the } \\
\text { scientific and innovation process. } \\
\text { The emphasis on the development of functional aspects of the } \\
\text { innovation system: cooperation, conditions for startups, regulation. } \\
\text { A large number of participants in the national innovation system, } \\
\text { active role of the coordinator (agency) in innovation policy }\end{array}$} \\
\hline $\begin{array}{l}\text { Support instruments for } R \& D \text { and innovation: } \\
\text { administration of the innovation system; development of } \\
\text { interaction "science-business-state" }\end{array}$ & \\
\hline $\begin{array}{l}\text { Leading national model of innovation development: } \\
\text { Triple helix model (Austria, Belgium, Brazil, Denmark, } \\
\text { France, Germany, Great Britain, Israel, Japan, the } \\
\text { Netherlands, Norway, South Korea, Switzerland, } \\
\text { Sweden, the USA) }\end{array}$ & $\begin{array}{l}\text { CONCEPT OF GROWTH THEORY: } \\
\text { Concept of formation of technological systems and diffusion of innovations } \\
\text { Combined model of endogenous growth. } \\
\text { The key role of production characteristics of the technological system }\end{array}$ \\
\hline \multicolumn{2}{|c|}{$\begin{array}{l}\text { FOURTH STAGE. } \\
\text { New target approach } \\
\text { (2009- present time) }\end{array}$} \\
\hline $\begin{array}{l}\text { Priority directions of state participation in } R \& D \text { : } \\
\text { information society, transition to an intellectual society, } \\
\text { demography, globalization, clean energy, sustainable } \\
\text { development, integration of poor countries, aging of } \\
\text { population }\end{array}$ & \multirow{2}{*}{$\begin{array}{l}\text { SPECIFICITY OF THE PERIOD: } \\
\text { Stability } \\
\text { Sustainable, rational, comprehensive growth, structural changes in } \\
\text { the economy, clear industrial and } \\
\text { technological goal-setting, in line with the needs of } \\
\text { global society as a whole. } \\
\text { Formation of a cluster economy model. } \\
\text { Integration of various social groups, horizontal policy coordination }\end{array}$} \\
\hline $\begin{array}{l}\text { Support instruments for } R \& D \text { and innovation: } \\
\text { symbiosis of administration and project financing; } \\
\text { development of interaction "state-society-business" }\end{array}$ & \\
\hline
\end{tabular}


End of Table

National model of innovation development:

Quadruple helix model, the principles of smart specialization, Industry 4.0 (Austria, Chile, China, Denmark, France, Finland,

Germany, Great Britain, Japan, Singapore, Vietnam, gaining development in Ukraine)

\section{CONCEPT OF GROWTH THEORY:}

Concept of balanced development

Structural factors of innovation development of the economy.

Structural dynamics: displacement mode, compensating

substitution mode; partial structure of the complete output

FIFTH STAGE.

Super-system approach

(2016 - present time)

Priority directions of state participation in $R \& D$ : robots, payment systems, genetic medicine

Support instruments for $R \& D$ and innovation:

legislative regulation

\section{SPECIFICITY OF THE PERIOD:}

Bias

Introduction of potentially devastating elements into the system, complete change of technological and social patterns.

"Breakthrough" technologies.

Commercialization and development of domestic market

(opportunities for growth), technology complementarity

(multi-application), industrial potential, research competencies.

Prioritization "bottom-up".

Disappearance of sectoral priority of enterprises.

Decisive role of business associations and research centers, the state is led

National model of innovation development:

Dual strategy-penetration of advanced technologies into traditional sectors, formation of new sectors (Great Britain, the USA).

"Society 5.0", "related industries" (Japan)

\section{CONCEPT OF GROWTH THEORY:}

Neoclassical concept - science, technology, innovations

Transition from depression to revival in the market.

Upsurge of business activity.

Lack of competition from old business.

Low risk of innovation.

Innovations determine the direction of development, increase the

market capacity for production factors, the entire output through the provision of grants, and encouraging the creation of research companies at universities and academic institutions. Legislative (including protection of intellectual property), financial, tax methods for stimulating innovation activity are used predominantly. Especially popular are various innovative structures (technoparks, technopolises, and others).

It should be noted that along with the basic production factors - labor and capital - and technological progress in terms of deepening globalization, interpreted as the third generalized production factor that initiates economic growth has gained an important role at this stage of countries' development. At the same time, the implementation of tight monetary policy in the 1990s contributed to the rapid stabilization of the exchange rate of the national currency of the countries of the Euro-Atlantic region, the growth of imports and compensatory exports, the development of export-oriented productions, the inflow of foreign capital and, consequently, the overall technological development and economic growth.

Within the industrial approach, the mechanisms of project financing are actively used together with the operational administration tools to form a special body of the country's innovation system.

This situation is typical for the system approach (2000-2008), which is based on market priorities and production characteristics of the technological system (the concept of formation of technological systems and the diffusion of innovations). In Western European countries, the processes of integrating national innovation systems into a single innovation space have been defined. That is the creation of a unified innovation system within the European Union, the development of special mechanisms for the intensification of innovation activities across the region (innovation networks, technology platforms, joint technological initiatives, the ESFRI roadmap and others). The tendencies of embedding the countries-members of "triple helix" in the national innovation systems have been outlined. This model was born on the basis of the Euro-Atlantic model. Particular importance is attached to the systematic coordination of actors from academic and business circles, public authorities for the purpose of developing innovation and economic growth on the basis of cooperation in the formation of regional clusters, the generation of innovation, knowledge and tools sharing.

The role of the state is expressed by participation in the process of developing managerial decisions related to the financing of $R \& D$ and innovation in the conditions of nonlinearity of scientific and innovative processes, the formation of national innovation systems. Administrating innovative systems through establishing links between researchers and innovators, providing information space are the main tools of innovation policy of countries. We also note that the third stage, reflecting the application of a combined model of endogenous growth, is accompanied by the complication of identifying key ideas that underpin basic innovations and industry developments. 
The basis of the new target approach (2009 - to present time) is the theory of cycles, innovations and conditions of innovative growth of the countries' economies that combine significant economic growth and structural changes in the composition of the intermediate product (structural dynamics: displacement mode, compensating substitution mode; partial structure of the complete output). In the modeling of structural factors of innovative growth of the economy, a direct reconstruction of the output composition is carried out, which is characteristic of an innovation-oriented economy. An example is the economic dynamics of industrialized countries that during the twentieth century have showed marked economic growth.

This approach is characterized by a clear industrial and technological goal-setting based on the needs of the global community as a whole. The modified model covers civil society actors (individuals, NGOs, consumer associations, and others). Within the transition to an intellectual society, welfare of citizens is based on the use of advanced service platforms on the basis of modern information technologies (artificial intelligence, Internet of things, robotics, and others) and human-machine interaction.

The central task of the declared new concept of economic growth is the transition to the concept of sustainable, balanced growth, where demand growth is supported by more intensive growth of supply due to increased business activity and competition in the domestic market, creating conditions for the formation of long investment resources, expansion of economy sectors oriented to external demand. The concept focuses on implementing the strategy of "smart specialization" within the framework of the "European Plan 2020" [12], which is based on the synthesis of previously fragmented knowledge in innovation and business: cooperation for innovation and dynamically interconnected processes of co-competition, co-evolution and co-specialization, both within the framework of regional (branch) innovation systems and outside of them. Intelligent specialization strategy is focused on efficient and synergistic use of public and private investment, promotes attraction of investors, embedding in European and global value-added chains. The main instrument of state support is the symbiosis of administration and project financing.

We should note that, according to studies and calculations of leading scientific institutions, Ukraine needs a scenario-based approach to balanced development, the implementation of which will create the preconditions for significant economic growth [13].

Thus, on October 26, 2017, at the Ministry of Economic Development and Trade of Ukraine a working meeting was held with the experts of the Joint Research Center (JRC) of the European Commission on the role of smart specialization for the economic and, above all, industrial development of Ukraine, the possibility of promoting the strengthening of mutual understanding between institutions of public administration, the use of European structural and investment funds. So, we can conclude that the involvement of the country into the
Smart Specialization Platform activities provides the transition to a national model of innovation development of the "quadruple helix" [14].

From 2016 to the present, a super-system approach has been developing which introduces potential destructive elements into the economic system and completely changes the current technological and social structures. It is assumed that in the next 20 years there will be a tendency for job cuts due to automation of work, replacement of human labor by robotic systems, medicine and transport development, creative activities, networking.

Under the advanced countries' experience the transition to the fifth level can only be formed in the presence of the national innovation system, application of portfolio approach (priority areas of research and development, creating the optimal portfolio of industries, technologies and support tools) and the organization of feedback in the industry and technological planning. Due to the fact that the only instrument of state influence on innovation processes of the fifth approach is legislative regulation, the strategies of innovation development of different countries contain a set of regulatory, educational, institutional and organizational measures.

Further, according to the structure of our study, we will define the problems and the feasibility of the stated model of intensive innovation development of the Ukrainian economy, namely the "quadruple helix".

Trends in Ukraine's transition to intensive innovative development. In recent years we have had a steady tendency to strengthen the striving of state authorities, business structures and the scientific sphere not only for sustainable growth of the economy, but also to increase its quality, primarily through the transition to an innovative way of development. This proved to be evident in the signing of the Partnership and Cooperation Agreement between Ukraine and the European Communities and their member states, the adoption by the country's leadership of the Strategy of Ukraine's Integration into the European Union, the Strategy of Economic and Social Development of Ukraine "Through European Integration for 2004-2015", strategist her economic and social development of Ukraine "European Integration for 2004-2015", Strategy of innovative development of Ukraine for 2010-2020 in terms of globalization challenges, the Concept of National Innovation System and Association Agreement with the European Union and the European Association.

Some areas that make the innovative model of economic development of Ukraine and measures for economic growth are defined by the Concept of scientific and technological and innovation development of Ukraine and the Medium-Term Plan of the Government's priority actions by 2020. But the pace of reforms slowed down after 2015, which threatens Ukraine's prospects for economic growth and innovation development. According to the authors, to remedy the situation, first of all, it is necessary to identify the factors of ineffective application of measures for state regulation of innovation development of Ukraine.

We should note that our further study is grounded by the content concept of quadruple helix [15], which is 
based on the balance of relations among the state, business, science and society in the implementation of the innovation process. The success of the model is conditioned by the presence of a well-established and effectively functioning national innovation system that performs traditional and new functions.

Proceeding from the above, the study on the readiness of Ukraine's transition to the model of intensive innovation development of the economy has been conducted by the authors in compliance with the components of the national innovation system of Ukraine (state regulation, education, knowledge generation, innovation infrastructure and production) and is defined as follows:

- barriers on the supply side: unresolved legal issues of distribution of intellectual property rights to the results of scientific research involving public-private partnerships; lack of funding and complexity in obtaining financial resources for innovative companies; low efficiency of the domestic system of commercialization of development of new technologies; the imbalance, the dispersal of the functions of public administration in the field of innovation development between central executive authorities; lack of entrepreneurial and innovative culture in the field of state research, and others;

- barriers on the demand side: insufficient interest of economic entities in the research and development; low demand for high-tech products and state-of-the-art scientific and innovation developments by the state, and others;

- barriers between "demand" and "supply": lack of effective official channels of information transfer from enterprises concerning expectations from science and education sector; insufficient experience of using publicprivate partnership in the field of innovations;

- lack of identified priorities: significant budget constraints; underdeveloped instruments to guarantee the attraction of private funds in innovation.

The presented conclusions allow one to assume that one of the main reasons for the unsatisfactory results of Ukraine's innovation development is the lack of mechanisms for "launching" an innovation model that are adequate to the current state of the Ukrainian economy and global challenges of the world, namely, the mechanism for managing innovation, which would be an effective system, built on the principles of modern state administration, administrative and innovative management.

Our conclusions are confirmed by the estimations of the Final Report of the Independent European Audit of the National System of Research and Innovation of Ukraine [16] and the World Economic Forum [17], according to which some critical operational factors of inhibition of Ukraine's development are the following: policy instability (12.1), access to financing (7.0), inadequately educated workforce (2.5), insufficient capacity for innovation (1.8) and inadequate supply of infrastructure (1.4). The overall negative impact of these factors on the national economy is causing a decline in society, increasing the risk of preserving Ukraine as a raw material appendage of the world economy. It should also be noted that due to ineffective state administration, Ukraine remains aside from world investment flows and processes-foreign investment in the national economy takes place on the model of underdeveloped countries.

We consider it necessary to note that, according to the Analytical Notes of the National Institute of SocioEconomic Research, four complementary reforms will contribute to the instruments of providing the inflow of a significant investment resource and innovative ideas, and hence changes in the economic model. They are as follows:

- change in the structure of Ukraine's economy;

- financial sector reform;

- investment reform;

- management system reform. However, the economic role of the state in the innovative development of the country, in the authors' opinion, should be the key one and implemented through the effective integration of public funding (institutional and project financing) and government incentives (tax incentives, preferential loans, guarantee loans through existing and newly established institutes).

However, for rapid growth, Ukraine must mobilize its efforts to reach a level that is more than $10 \%$ of annual economic growth [18]. But the likelihood of achieving such indicators is estimated at $3 \%$. Lower socioeconomic results of Ukraine do not provide the possibility to overcome the crisis (Fig. 1).

According to the data presented, in the countries of the world and the EU there is an increasing tendency for the index during 1970-2017 (growth rate is 92.19 and $94.14 \%$, respectively). However, in Ukraine there is a negative trend of the indicator $--22.72 \%$ for the specified period.

This is explained by the improper development of the institutional system of Ukraine, long-term systemic strategic miscalculations in the area of monetary policy, currency and banking regulation, economic, financial and institutional policies. In turn, during the period under study industrially developed countries and countries with catching-up economies created powerful national innovation systems, the effective functioning of which is provided by a combination of industrial and information technology, instruments of state management, an appropriate institutional structure, monetary and financial regulation.

Substantiating the necessity of implementation of the management model of innovative development of the Ukrainian economy. Defining the role of public authorities, research processes sharing responsibilities in the area of innovation policy management within the na-

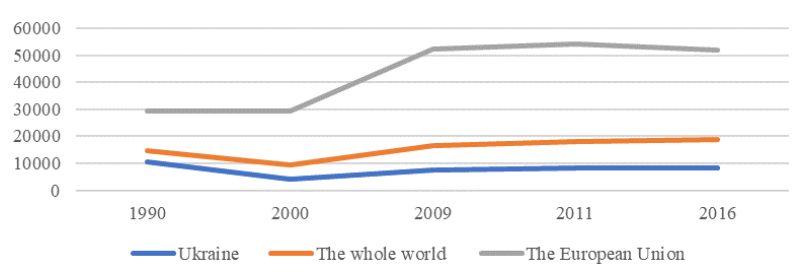

Fig. 1. Dynamics of GDP per capita for the world countries over 1990-2016, PPP, billion dollars USA [19] 
tional innovation system enabled the authors to conclude that there is proper coordination in those countries that have close ties and constant discussion of development programs with coordinating bodies and participation of all interested individuals and organizations. State regulation of innovation activity is considered as a complex of relevant levers and instruments aimed at establishing and implementing legal and organizational relations between public authorities and innovation actors (subjects).

It should be noted that, following the recommendations of the commission of independent experts and leading experts of the relevant ministries of the EU countries, Ukraine needs to develop an interagency Strategy for the development of science, technology and innovation, which involves the use of intellectual, material and financial assets of the country. Today, the first step towards implementing the reforms of the national system of science, technology and innovation in Ukraine is the creation of a new coordinating body - the National Council for Science and Technology Development. However, the challenge still remains to determine the responsibility and priority directions of science and technology and innovative development of Ukraine on the basis of the principle of "top-down", which requires the establishment of an effective mechanism for coordination between organizations, government agencies and departments responsible for the development and implementation of innovation policy on the principle of horizontal integrity Based on the above, the authors propose the following model of managing the process of innovation development (Fig. 2).

According to the figure, the integrator, the only center for the coordination of all institutes, plays a crucial role in the coordination mechanism of innovation policy.

The authors have identified the National Council for Science and Technology Development as such a center. In accordance with the Resolution of the Cabinet of Ministers of Ukraine "On the Establishment of the Council for the Development of Innovations", the Provision of 25.10.2017, No. 895 [20, 21], 34 subjects were assigned to the collegial body, where the Chairman of the Council is the Prime Minister of Ukraine. However, it should be noted that the "Regulations on the Innovation Development Council" do not establish "leaders" of innovation policy at the level of state authorities (definition of powers, expediency of the use of instruments), which, according to the authors, is the main reason for the low level of co-ordination of Ukraine's innovation policy. It is equally important to identify and implement the functions of the subjects of management of innovation development and support tools.

We also consider it necessary to note that world practice proves the need for adequate financial support

CHALLENGES FOR THE DEVELOPMENT OF INNOVATION SPHERE:

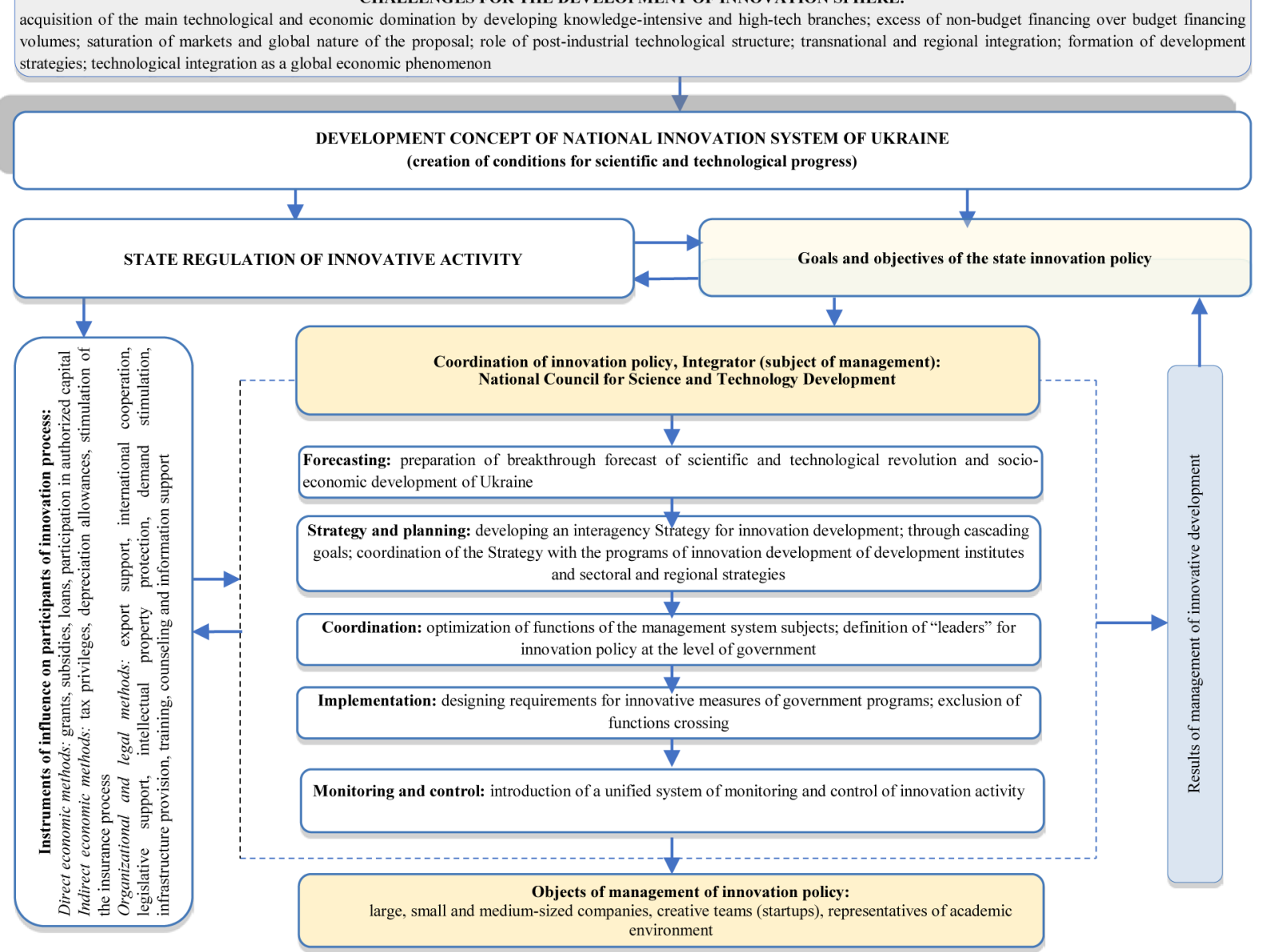

Fig. 2. Scheme model of managing innovative development of Ukraine's economy 
for the country's scientific, technical and innovative development, the main sources of which are its own production resources and banking system loans. Budget financing, as a rule, provides only fundamental science and interest reimbursement for loans received for the introduction of new technologies. The insufficiency of the financial support updates the issue of attracting investment or external borrowing. We emphasize that the essence of the problem in Ukraine is not so much in the scope of budget financing as in the existing system of management of this process, in the mechanism of implementing the main objectives of the state innovation policy.

Conclusions and recommendations for further research in this area.

1. It was investigated that in the evolution of innovation development concepts, five basic approaches to the implementation of innovation policy were identified:

- traditional approach, targeting research and development system as the main source of innovation;

- industrial approach, whereby the priorities of state participation in $\mathrm{R} \& \mathrm{D}$ is a large-scale project financing and operational administration;

- systemic approach, recognizing national innovation systems and clusters as the main sources of innovation;

- new target approach, which declares the application of the principles of interaction among the state, society and business as a basis of the leading national model of innovative development;

- super-system approach, which is in the prospect and involves the possibility of using the existing potential for innovation in other sectors of economy by crosssectoral optimizing the components of innovative policy through coordination and integration.

2. It is determined that today the national innovation system of Ukraine is in the stage of formation and has a number of shortcomings, among which we would like to highlight the following:

- weak financial support of institutes;

- low level of interaction of the state, institutes and elements of the national innovation system;

- low innovative activity of the commercial sector;

- low demand for innovative products and, in general, low development level of innovation culture in Ukraine.

3. It is proved that the model of intensive innovation development is intended to provide structural changes in the economic process of the country and improve its technological level. It is proposed to introduce a mechanism for coordination and control over the development of innovation activities by the state, relevant institutes and regulators in order to achieve synergy effect and balanced economic growth of the national economy of Ukraine.

4. It is recommended, as a further development, to provide innovative development of Ukraine at the expense of internal and external investments, which involves the construction of the appropriate financialcredit mechanism by:

- creating a network of specialized financial development institutes;
- attracting foreign investment from international companies by providing state guarantees to the most important programs (infrastructure, logistics, regional, and others);

- ensuring a favorable investment climate, which involves updating the mechanism for project financing and implementation of cluster model for large-scale lending innovation programs.

\section{References.}

1. RAND Corporation, 2006. The Global Technology Revolution 2020, In-Depth Analyses. Bio/Nano/Materials/Information Trends, Drivers, Barriers, and Social Implications [pdf]. Available at: <https://www.rand.org/ content/dam/rand/pubs/technical_reports/2006/ RAND_TR303.pdf $>$ [Accessed 2 August 2017].

2. Glaz'ev, S., 2011. On strategy of development and modernization of economy of Russia in terms of global depression. Ekomika regiona [online], 2, pp. 14-25. Available at: $<$ https://cyberleninka.ru/article/v/o-strategii- modernizatsii-i-razvitiya-ekonomiki-rossii-v-usloviyah-globalnoydepressii> [Accessed 11 September 2017].

3. Teulings, C. and Baldwin, R., eds., 2014. Secular stagnation: Facts, causes and cures. A VoxEU.org eBook. London: Centre for Economic Policy Research (CEPR) [online]. Available at: <https://voxeu.org/article/secular-stagnation-facts-causes-and-cures-new-vox-ebook> [Accessed 5 July 2017].

4. Geets, V., 2008. The problematic issues of innovative way of the economy development in Ukraine. Naukoviy zhurnal Visnik Institutu Ekonomiki ta prognozuvannya [online], pp. 3-11. Available at: <http://ief.org.ua/wpcontent/uploads/2014/09/Visnyk2008.pdf $>$ [Accessed 27 August 2017].

5. European Commission, 2017. Communication from the Commission to the European Parliament, the Council, the European Economic and Social Committee and the Committee of the Regions and the European Investment Bank. Investing in a smart, innovative and sustainable Industry A renewed EU Industrial Policy Strategy COM [online]. Available at: <http://eur-lex.europa.eu/resource. html?uri=cellar:c8b9aac5-9861-11e7-b92d-01aa75ed71a1.0001.02/DOC_1\&format $=$ PDF $>$ [Accessed 7 November 2017].

6. NATO, 2015. Technology Trends Survey. Future Emerging Technology Trends. Version 3. A Food-forThought Paper to Support the NATO Defence Planning Process [online]. Available at: <http://www.act.nato. int/images/stories/events/2012/fc_ipr/technology_ trend_survey_v3.pdf $>$ [Accessed 12 June 2017].

7. National Intelligence Council, 2012. Global trends 2030: alternative worlds [pdf]. Available at: <https://globaltrends2030.files.wordpress.com/2012/11/globaltrends-2030-november2012.pdf> [Accessed 8 August 2017].

8. Keidanren (Japan Business Federation), 2016. Toward realization of the new economy and society [pdf]. Available at: <https://www.keidanren.or.jp/en/policy/2016/029_outline.pdf> [Accessed 12 May 2018]. 9. Leydesdorff, L., 2012. The Triple Helix, Quadruple Helix, ..., and an N-Tuple of Helices: Explanatory 
Models for Analyzing the Knowledge-Based Economy? Journal of the Knowledge Economy [online], 3, pp. 2535. Available at: $<$ https //https://link.springer.com/article/10.1007/s13132-011-0049-4> [Accessed 12 October 2017].

10. Virkkala, S., Mäenpää, A. and Mariussen A., eds., 2014. The Ostrobothnian model of smart specialization. In: Proceedings of the University of Vaasa Reports 195. Vaasa: University of Vaasa [pdf]. Available at: <https:// www.uva.fi/materiaali/pdf/isbn_978-952-476-577-0. pdf> [Accessed 23 November 2017]].

11. Ministry of Economic Development and Trade of Ukraine, 2016. Project Strategies for development of industrial complex of Ukraine. It was developed in compliance with p.101 of the Government Action Plan for 2017. Kyiv: Ministry of Economic Development and Trade of Ukraine [online]. Available at: <https://issuu.com/ mineconomdev $>$ [Accessed 8 February 2018].

12. European Commission, 2010. Europe 2020: A strategy for smart, sustainable and inclusive growth. COM(2010) 2020 final [online]. Available at: <http:// eur-lex.europa.eu/LexUriServ/LexUriServ.do?uri=CO M:2010:2020:FIN:EN:PDF> [Accessed 18 November 2017].

13. Antoniuk, L., Humenna, O. and Radchuk, A., 2017. Ukraine 2030: The doctrine of balanced development, 2nd ed. Lviv: Calvary [online]. Available at: <http://econom. chnu.edu.ua/wp-content/uploads/2018/03/E-BookDoctrine-2030.pdf $>$ [Accessed 24 January 2018].

14. MINPROM information agency, 2017. Ukrmetallurgprom supported the introduction of smart specialization. News [online]. Available at: <Retrieved from: // https://www.minprom.ua/news/236893.html $>$ [Accessed 20 February 2018].

15. Carayannis, E. and Rakhmatullin, R., 2014. The Quadruple/Quintuple Innovation Helixes and Smart Specialization Strategies for sustainable and inclusive growth in Europe and beyond. Journal of the Knowledge Economy [pdf], 2, vol. 5, pp. 212-239. Available at: <https://foresight-journal.hse.ru/data/2016/04/14/1129617631/3-Carayannis-31-42.pdf $>$ [Accessed 21 October 2017].

16. European Commission, 2017. The final report of the European independent audits of national research and innovation system of Ukraine. Political support tool for program "Horizon 2020". Summary and Recommendations to improve sectoral policies [online]. Available at: <https://rio.jrc.ec.europa.eu/en/file/10484> [Accessed 15 January 2018].

17. World Economic Forum. Geneva, 2017. The Global Competitiveness Report 2017-2018 [online]. Available at: <http://www3.weforum.org/docs/GCR2017-2018/ 05FullReport/TheGlobalCompetitivenessReport 2017 $\%$ E2\%80\%932018.pdf> [Accessed 11 October 2017].

18. NTUU “KPI named after Igor Sikorsky". World Data Center for Geoinformatics and Sustainable Development, 2016. Foresight and construction of a strategy of social and economic development of Ukraine for the medium-term (until 2020) and long-term (until 2030) time horizons [pdf]. Available at: <http://ied.kpi.ua/wp-content/uploads/2015/09/WDC-IASA-FORESIGHT2016.pdf $>$ [Accessed 24 May 2017].
19. The World Bank, 2016. GNI, Atlas method (current prices) (USD) REAL GDP per capita in PPS (dollars) in the European Union (28), Ukraine and the whole world] Trend Economy. Catalog of data. The World Bank's data [online]. Available at: <http://data.trendeconomy.ru/ dataviewer/wb/wbd/wdi?kf=WDI\&time_period $=1990$ ,2000,2009,2011,2016\&ref_area=EUU,UKR，WLD\& series $=$ NY_GDP_PCAP_PP_KD,NY_GNP_ATLS $\mathrm{CD}>$ [Accessed 05 February 2018].

20. The Ministry of Education and Science of Ukraine, 2018. The strategy of Ukraine's innovation development will consider the Israeli experience, - Lilia Grinevich at the Israel Ministerial Conference in 2018. Government portal [online]. Available at: <https://www.kmu.gov.ua/ ua/news/strategiya-innovacijnogo-rozvitku-ukrayinivrahovuvatime-izrayilskij-dosvid-liliya-grinevich-nanaukovij-ministerskij-konferenciyi-v-izrayili> [Accessed 20 May 2018].

21. The Cabinet of Ministers of Ukraine, 2017. Provisions of the Cabinet of Ministers of Ukraine on formation of the Council for innovations development (2017, October 25) [online]. Available at: <zakon5.rada.gov. ua/laws/show/895-2017-\%D0\%BF\#n12> [Accessed 29 December 2017].

\section{Модель інтенсивного інноваційного розвитку: світовий досвід реалізації та тенденції формування в України}

\section{М. І. Звєряков, Д. В. Завадська}

Одеський національний економічний університет, м. Одеса, Україна e-mail: rector@oneu.edu.ua; zavadska. diana@ukr.net

Мета. Розробка рекомендацій щодо реалізації моделі інтенсивного інноваційного розвитку в Україні.

Методика. Інформаційною базою дослідження є дані оглядів з інноваційного розвитку країн і результати наукових доробок українських і закордонних учених, які опубліковані в монографічних дослідженнях і публікаціях у періодичних виданнях. Офіційну статистичну базу становлять дані міжнародних організацій і провідних наукових інституцій України. Під час проведення дослідження використані методи табличного та графічного подання результатів дослідження, логічного узагальнення, порівняльного аналізу й системного підходу, що враховує динамічну функціональну залежність між станом цілого, розвитком і збалансованістю його складових елементів.

Результати. У роботі підкреслюється, що проблема економічного зростання та інноваційного розвитку набула особливої значимості. Доведено, що модель інтенсивного інноваційного розвитку покликана забезпечити структурні зрушення в економічному стані країни та підвищити її технологічний рівень. Критичний аналіз наукових доробок провідних учених та оцінка сучасного стану інноваційної національної системи України дозволили ді- 
йти висновку щодо відсутності механізмів ,запуску“ інноваційної моделі, адекватних сучасному стану економіки та глобальним викликам світу. 3 метою досягнення синергічного ефекту та збалансованого економічного зростання національної економіки України запропоновані практичні заходи впливу інструментів державного регулювання інноваційної діяльності.

Наукова новизна. У роботі доводиться особлива роль Національної ради з питань розвитку науки й технологій в якості інтегратора, що визначається виконанням спеціальних функцій управління, направлених на підвищення рівня скоординованості інноваційної політики України.

Практична значимість. Полягає в тому, що наукове дослідження чітко, зрозуміло й послідовно доводить нагальну необхідність переходу та заходи реалізації моделі четверної спіралі інноваційного розвитку економіки України. Отримані результати в подальшому будуть використані для розробки рекомендацій із визначення напрямів фінансового забезпечення $з$ метою активізації інноваційних процесів країни.

Ключові слова: економічні теорії, концепції зростання, інноваційний розвиток, модель, підхід, держава, інструменти регулювання, координація

\section{Модель интенсивного инновационного развития: мировой опыт реализации и тенденции формирования в Украине}

\section{М. И. Зверяков, Д. В. Завадская}

Одесский национальный экономический университет, г. Одесса, Украина, e-mail: rector@oneu.edu.ua; zavadska. diana@ukr.net

Цель. Разработка рекомендаций по реализации модели интенсивного инновационного развития в Украине.

Методика. Информационной базой исследования являются данные обзоров по инновационному развитию стран и результаты научных разработок украинских и зарубежных ученых, опубликованных в монографических исследованиях и публикациях в периодических изданиях. Официальную статистическую базу составляют данные международных организаций и ведущих научных институтов Украины. При проведении исследования ис- пользованы методы табличного и графического представления результатов исследования, логического обобщения, сравнительного анализа и системного подхода, учитывающего динамическую функциональную зависимость между состоянием целого, развитием и сбалансированностью его составляющих элементов.

Результаты. В работе подчеркивается, что проблема экономического роста и инновационного развития приобрела особую значимость. Доказано, что модель интенсивного инновационного развития призвана обеспечить структурные сдвиги в экономическом состоянии страны и повысить ее технологический уровень. Критический анализ научных разработок ведущих ученых и оценка современного состояния инновационной национальной системы Украины позволили сделать вывод об отсутствии механизмов „запуска“ инновационной модели, адекватных современному состоянию экономики и глобальным вызовам мира. С целью достижения синергетического эффекта и сбалансированного экономического роста национальной экономики Украины предложены практические меры воздействия инструментов государственного регулирования инновационной деятельности.

Научная новизна. В работе доказывается особая роль Национального совета по вопросам развития науки и технологий в качестве интегратора, которая определяется выполнением специальных функций управления, направленных на повышение уровня скоординированности инновационной политики Украины.

Практическая значимость. Заключается в том, что научное исследование четко, понятно и последовательно доказывает настоятельную необходимость перехода и меры реализации модели четверной спирали инновационного развития экономики Украины. Полученные результаты в дальнейшем будут использованы при разработке рекомендаций по определению направлений финансового обеспечения с целью активизации инновационных процессов в стране.

Ключевые слова: экономические теории, концепции роста, инновационное развитие, модель, подход, государство, инструменты регулирования, координация

Рекомендовано до публікації докт. екон. наук В.М.Тарасевичем. Дата надходження рукопису 14.09.17. 